\title{
Pengaruh Pembatasan Sosial dan Variabel Ekonomi Terhadap Prevalensi Pandemi Covid-19 di Provinsi Jawa Barat
}

\author{
The Effect of Social Restrictions and Economic Variables on The Prevalence of \\ The Covid-19 Pandemic in West Java Province
}

\author{
Jordi Aperdanaste ${ }^{1}$, Alfiah Hasanah ${ }^{2}$, Adiatma Yudistira Manogar Siregar ${ }^{2}$ \\ ${ }^{1}$ Magister Ilmu Ekonomi, Fakultas Ekonomi dan Bisnis, Universitas Padjadjaran \\ ${ }^{2}$ CEDS, Departemen Ilmu Ekonomi, Fakultas Ekonomi dan Bisnis, Universitas Padjadjaran
}

Korespondensi: Jordi Apedanaste

E-mail: jordi19002@mail.unpad.ac.id

\begin{abstract}
Abstrak
Ada banyak faktor yang dapat mempengaruhi pembatasan sosial terhadap penurunan jumlah kasus Covid-19 di 27 Kota dan Kabupaten di Provinsi Jawa Barat. Penelitian ini bertujuan untuk mengetahui pengaruh dari pembatasan sosial dan variabel ekonomi terhadap pandemi Covid-19 di Provinsi Jawa Barat. Penelitian ini menggunakan beberapa data yang bersumber dari Pusat Informasi \& Koordinasi Covid-19 Provinsi Jawa Barat, dan Badan Pusat Statistik Provinsi Jawa Barat. Variabel terikat pada penelitian ini adalah rata-rata penambahan kasus harian Covid-19. Sedangkan, variabel bebas pada penelitian ini adalah dummy pembatasan sosial, kepadatan penduduk, PDRB per kapita, tingkat pendidikan, tingkat mobilitas, tingkat pengangguran, jumlah tenaga kesehatan, persentase penduduk miskin, dan angka harapan hidup. Semua data tersebut dikumpulkan dalam periode antara 2 Maret 2020 hingga 2 Maret 2021 yang terdiri dari 17 periode berdasarkan Surat Keputusan Gubernur Jawa Barat. Analisis data panel dengan pendekatan Feasible Generalized Least Square (FGLS) diterapkan dengan menggunakan perangkat lunak Stata MP64. Hasil penelitian menunjukkan bahwa pembatasan sosial, kepadatan penduduk, tingkat pengangguran, dan jumlah tenaga kesehatan berpengaruh positif dan signifikan terhadap penurunan kasus Covid-19 di Provinsi Jawa Barat. PDRB per kapita berpengaruh positif terhadap penurunan kasus Covid-19, namun tidak signifikan. Tingkat pendidikan, tingkat mobilitas, persentase penduduk miskin, dan angka harapan hidup berpengaruh negatif dan signifikan terhadap penurunan kasus Covid-19 di Provinsi Jawa Barat. Oleh karena itu, pembatasan sosial merupakan kebijakan yang tepat guna menurunkan pandemi Covid-19 di Provinsi Jawa Barat.

Kata kunci: Pembatasan Sosial, Pandemi, Covid-19, Jawa Barat, FGLS.
\end{abstract}

\begin{abstract}
There are numerous factors that might affect social restrictions regulation on the reduction of the number of Covid-19 cases in 27 cities and districts in West Java Province. This study aims to identify the effect of social restrictions and economic variables on Covid19 pandemic in West Java Province. The investigation uses several data sourced from the Covid-19 Information \& Coordination Center of West Java Province, and the Central Bureau of Statistics in West Java Province. The dependent variable in this study is the average increase in daily Covid-19 cases. Meanwhile, the independent variable in this study are dummy of social restrictions, population density, per capita GRDP, education level, mobility level, unemployment rate, number of health workers, percentage of the poor population, and life expectancy. All the information gathered in the period between March 2, 2020 and March 2, 2021, which consists of 17 periods based on the Decree of the Governor of West Java. A panel data analysis with the Feasible Generalized Least Square (FGLS) approach is applied using Stata MP-64 software. The results show that social restrictions, population density, unemployment rate, and the number of health workers have a positive and significant effect against the reduction of the Covid-19 cases in West Java Province. Per capita GRDP shows a positive effect against the reduction of the Covid-19 cases, however it is not significant. Level of education, level of mobility, percentage of the poor population, and life expectancy have a negative and
\end{abstract}


significant effect against the reduction of the Covid-19 cases in West Java Province. Therefore, social restrictions are the right policies to reduce the Covid-19 pandemic in West Java Province.

Keywords: Social Restrictions, Pandemic, Covid-19, West Java, FGL

\section{Pendahuluan}

Covid-19 (Corona Virus Disease) merupakan penyakit pandemi yang dinyatakan oleh World Health Organization sejak 9 Maret 2020 (WHO, 2020). Covid-19 terdeteksi pertama kali di Indonesia sejak 2 Maret 2020, kemudian menyebar di seluruh 27 Kota dan Kabupaten di Provinsi Jawa Barat (Pikobar, 2021). Terdapat kenaikan kasus sejak tanggal 2 Maret 2020 setiap hari, sehingga per tanggal 2 Maret 2021 total kasus Covid-19 di Provinsi Jawa Barat adalah 214.529 orang (Pikobar, 2021). Adapun data terbaru total kasus Covid-19 di Provinsi Jawa Barat per 27 November 2021 adalah 707.674 orang di Provinsi Jawa Barat (Pikobar, 2021).

Pada Gambar 1, grafik menunjukkan pertumbuhan ekonomi di Provinsi Jawa Barat maupun nasional, serta peningkatan prevalensi kuartal ke kuartal (Q to Q) di Provinsi Jawa Barat pada Triwulan II, III, dan IV (BPS, 2020). Pada triwulan II (April-Juni 2020) dan triwulan III (JuliSeptember 2020), pertumbuhan ekonomi di Provinsi Jawa Barat berada di bawah pertumbuhan ekonomi nasional (BPS Jawa Barat, 2020). Sementara itu, peningkatan kasus Covid-19 pada triwulan II dan III mengalami penurunan jika dibandingkan periode sebelumnya. Peningkatan prevalensi Covid-19 di Provinsi Jawa Barat sebesar 15,32 kali lebih besar pada Triwulan II daripada Triwulan I (Pikobar, 2021). Sedangkan peningkatan prevalensi Covid-19 di Provinsi Jawa Barat pada triwulan III hanya 5,25 kali lebih besar daripada Triwulan II (Pikobar, 2021). Kemudian, pada Triwulan IV (Oktober-Desember 2020) peningkatan prevalensi Covid-19 di Provinsi Jawa Barat sebesar 2,23 kali lebih besar pada Triwulan IV daripada Triwulan III. Jika dibandingkan dengan Triwulan IV, maka menurut data BPS
Jawa Barat (2020) pertumbuhan ekonomi Q to Q di Provinsi Jawa Barat dan nasional, serta peningkatan prevalensi Covid-19 mengalami penurunan (Pikobar, 2021).

Walaupun terjadi penurunan pertumbuhan ekonomi pada Triwulan IV di Provinsi Jawa Barat, pertumbuhan ekonomi di Provinsi Jawa Barat pada Triwulan IV Tahun 2020 masih berada di area positif jika dibandingkan dengan pertumbuhan ekonomi nasional (BPS Jawa Barat, 2020). Hal ini menunjukkan bahwa di masa krisis ini, provinsi Jawa Barat masih dapat menunjukkan kinerja pertumbuhan ekonomi di Provinsi Jawa Barat yang positif sebesar $0,22 \%$ di saat pertumbuhan ekonomi nasional $-0,42 \%$. Hal ini diduga dipengaruhi oleh implementasi program pemulihan ekonomi nasional (PEN) yang berhasil pada Provinsi Jawa Barat (BPS, 2020). Oleh karena itu, agar dapat menerapkan kebijakan pemulihan ekonomi nasional secara konsisten di tengah pandemik, maka diperlukan analisa pengaruh dari pembatasan sosial lebih lanjut.

Pembatasan Sosial Berskala Besar merupakan upaya pemerintah pusat yang diterapkan selain pada sebelas sektor yaitu kesehatan, komunikasi dan teknologi informasi, bahan pangan, energi, keuangan, perhotelan, konstruksi, logistik, publik dan industri yang ditetapkan sebagai objek vital nasional, dan objek tertentu, serta kebutuhan sehari-hari (JDIH, 2021). Hasil dari penerapan kebijakan pembatasan sosial ini pada berbagai negara efektif dalam menurunkan jumlah kasus Covid-19 (Fang dkk., 2021). Goolsbee dan Syverson (2021) menyatakan bahwa dampak kebijakan pembatasan sosial akan mengurangi jumlah kunjungan konsumen pada bisnis yang "dilarang" untuk beroperasi. Pada akhirnya, 
pandemi tidak hanya menyebabkan kerugian kehidupan tetapi menjukirbalikan ekonomi dan menciptakan kekacauan sosial di berbagai negara di dunia (Brundtland, 2019).

Penerapan pembatasan sosial di Provinsi Jawa Barat dilakukan secara zonasi berdasarkan tingkat keparahan penyebaran pandemi Covid-19 di daerah tersebut. Kebijakan ini mulai diberlakukan pada tanggal 15 April 2020 dengan diawali pada 5
Kabupaten Kota saja di Provinsi Jawa Barat yang menerapkan pembatasan sosial, hingga diberlakukan di seluruh 27 Kota dan Kabupaten di Provinsi Jawa Barat sejak tanggal 6 Mei 2020 (JDIH, 2021). Sedangkan, dampak pandemi Covid-19 di Indonesia khususnya terjadi pada sektor perdagangan, manufaktur, sektor jasa, pariwisata dan penerbangan (Feyisa, 2020).

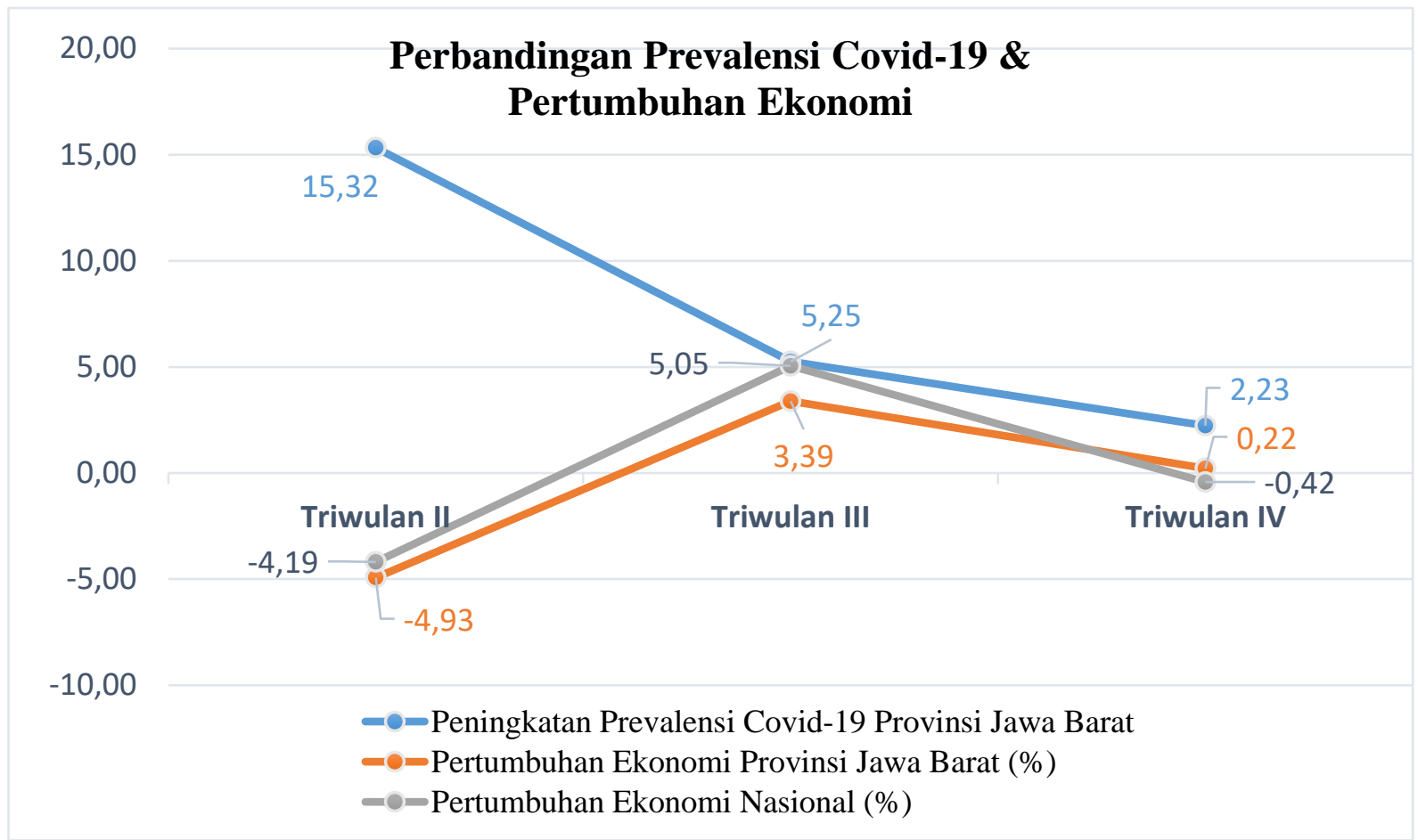

Gambar 1. Grafik Perbandingan Antara Peningkatan Prevalensi Covid-19, Pertumbuhan Ekonomi Provinsi Jawa Barat dan NasionalTriwulan II-IV Tahun 2020 (Pikobar, 2021), (BPS Jawa Barat, 2020).

Oleh karena itu, pentingnya untuk melakukan penelitian ini, sebab faktanya terdapat hubungan yang dapat diukur lebih lanjut antara jumlah penularan Covid-19 dengan kepadatan penduduk (Taipale dkk., 2020). Data kepadatan penduduk dapat digunakan untuk menganalisa faktor penyebaran pandemi Covid-19 dan bermanfaat bagi pembuat kebijakan kesehatan masyarakat maupun tenaga kesehatan untuk mengenali target populasi dalam mencegah penularan Covid-19 dan pendidikan kesehatan (Zhong dkk., 2020). Beberapa aspek harus diukur dan dianalisa secara teliti seperti pengaruh pembatasan sosial dalam hal kepadatan penduduk, Produk Domestik Regional Bruto (PDRB) per kapita, tingkat pendidikan, tingkat mobilitas, tingkat pengangguran, jumlah tenaga kesehatan, tingkat penduduk miskin, dan angka harapan hidup.

Berbagai upaya yang telah dilakukan oleh pemerintah Provinsi Jawa Barat yang diduga dapat 
mengendalikan jumlah kasus Covid-19 di Provinsi Jawa Barat, salah satunya dengan menerapkan pembatasan sosial secara zonasi berdasarkan Keputusan Gubernur Provinsi Jawa Barat dan bekerjasama dengan Satuan Gugus Tugas Covid19 dengan harapan pertumbuhan ekonomi pada sebelas sektor tersebut dapat berjalan dengan baik. Berdasarkan data tersebut maka perlu dilakukan penelitian pengaruh pembatasan sosial di Provinsi Jawa Barat yang didukung dengan pemikiran teori dan data ekonomi kesehatan yang dikembangkan (BPS Jawa Barat, 2020).

\section{Metode Penelitian}

Penelitian ini merupakan penelitian noneksperimental dengan menggunakan data retrospektif dari Badan Pusat Statistik (BPS), Pusat Informasi dan Koordinasi Covid-19 Jawa Barat (Pikobar). Periode data yang digunakan adalah 2 Maret 2020 sampai dengan 2 Maret 2021 di 27 Kota dan Kabupaten di Provinsi Jawa Barat (Pikobar). Data dikelompokan menjadi 17 periode waktu mengikuti peraturan jumlah hari pada penerapan pembatasan sosial menurut Keputusan Gubernur Provinsi Jawa Barat. Adapun model persamaan pada penelitian ini, sebagai berikut:

$$
\begin{gathered}
\mathrm{Y}_{i t}=\alpha_{i t}+\beta_{1} \mathrm{D}_{i(t-k)}+\beta_{2} \mathrm{KP}_{i t}+\beta_{3} \mathrm{~PB}_{i t}+\beta_{4} \mathrm{TP}_{i t}+ \\
\beta_{5} \mathrm{TM}_{i t}+\beta_{6} \mathrm{UM}_{i t}+\beta_{7} \mathrm{TK}_{i t}+\beta_{8} \mathrm{PM}_{i t}+\beta_{9} \mathrm{AH}_{i t}+\mathrm{e}_{i t}
\end{gathered}
$$

Keterangan:

$$
\begin{array}{lll}
\mathrm{Y} & : & \text { Rata-Rata Penambahan Kasus } \\
& \text { Harian Covid-19 (Jumlah Kasus } \\
& \text { Covid-19 perhari) } \\
\alpha \quad: & \text { Konstanta } \\
\beta_{1-} \beta_{9}: & \text { Parameter }
\end{array}
$$

$\mathrm{D}_{(\mathrm{t}-\mathrm{k})} \quad$ : Variabel dummy pembatasan sosial pada selang waktu ( $1=$ Ada pembatasan sosial, $0=$ Tidak ada pembatasan sosial)

KP : Kepadatan Penduduk (Jiwa/ $\left./ \mathrm{km}^{2}\right)$

PB : PDRB per kapita

TP : Tingkat Pendidikan (Angka Pendidikan Kasar)

TM : Tingkat Mobilitas (Angka Migrasi Netto)

UM : Tingkat Pengangguran (Pengangguran Terbuka)

TK : Jumlah Tenaga Kesehatan (Dokter, Bidan, Perawat, Farmasi, dan Ahli Gizi)

PM : Persentase Penduduk Miskin

AH : Angka Harapan Hidup

$i \quad:$ Objek ke- $i(1, \ldots, 27)$

$t \quad:$ Periode ke- $t(1, \ldots, 17)$

e : Komponen galat

Pembatasan sosial sekarang (periode I) akan berdampak pada pada RPKH periode setelahnya (periode II)

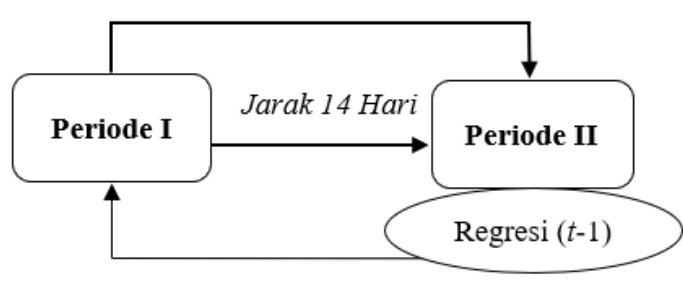

Analisa dengan meregresi RPKH periode sekarang (periode II) yang diakibatkan oleh pembatasan sosial pada periode sebelumnya (periode I)

Gambar 2. Alur analisa regresi model distributed lag 
Tabel 1. Deskripsi Data

\begin{tabular}{|c|c|c|}
\hline Definisi Operasional Variabel & Indikator & Keterangan \\
\hline $\begin{array}{l}\text { Rata-rata penambahan kasus Covid-19. } \\
\text { Setiap harinya pada periode waktu tertentu di } \\
27 \text { Kota dan Kabupaten di Provinsi Jawa Barat } \\
\text { Dimensi }=\Sigma \text { Kasus Covid-19 (orang)* } \Sigma \text { Hari* } \\
\text { *dalam suatu periode yang sama (Pikobar, } \\
2020 \text { ) }\end{array}$ & $\begin{array}{ll}\text { - } & \text { Keputusan dan } \\
\text { Peraturan Gubernur } \\
\text { Provinsi Jawa Barat } \\
\text { - Data harian Covid-19 } \\
\text { (Pikobar) } \\
\text { - Penelitian Cheng } \\
\text { (2020) masa terlama } \\
\text { pasien Covid-19 dapat } \\
\text { dinyatakan sembuh } \\
\text { adalah } 14 \text { hari }\end{array}$ & \\
\hline
\end{tabular}

Pembatsan Sosial: Kebijakan yang diterapkan oleh Pemerintah Provinsi Jawa Barat di 27 Kota dan Kabupaten di Provinsi Jawa Barat dengan melarang masyarakat untuk memasuki atau meninggalkan suatu daerah tertentu secara bebas maksud dengan maksud menghentikan penyebaran Covid-19 (Pikobar, 2020).

Kepadatan Penduduk: Banyaknya penduduk per satuan luas di 27 Kota dan Kabupaten di Provinsi Jawa Barat.

PDRB per Kapita: Nilai PDRB dibagi jumlah penduduk dalam suatu wilayah per periode tertentu di 27 Kota dan Kabupaten di Provinsi Jawa Barat.

Tingkat Pendidikan: Angka pendidikan kasar di 27 Kota dan Kabupaten di Provinsi Jawa Barat yang berpendidikan SMA dan Perguruan Tinggi (PT).

Data BPS Jawa Barat 2020

- Level: Setiap kota dan kabupaten di Provinsi Jawa Barat

- Periode: 17 periode waktu (setiap periode terdiri dari 14 hari jumlah migrasi masuk dan migrasi keluar.

Tingkat pengangguran terbuka terhadap jumlah angkatan kerja di 27 Kota dan Kabupaten di Provinsi Jawa Barat.

Jumlah tenaga kesehatan yang terdiri dari dokter, perawat, bidan, farmasi, dan ahli gizi di 27 Kota dan Kabupaten di Provinsi Jawa Barat.

Persentase penduduk di 27 Kota dan Kabupaten di Provinsi Jawa Barat yang berada dibawah garis kemiskinan.

Angka Harapan Hidup: Rata-rata perkiraan lama masa hidup sesorang yang dapat ditempuh di 27 Kota dan Kabupaten di Provinsi Jawa Barat. 
Model penelitian ini termasuk distributed-lagmodel yaitu model yang memperlihatkan antara variabel terikat dan variabel bebas yang didistribusikan menurut periode waktu tertentu (Gujarati, 1988). Sebagai contoh pada penelitian ini pembatasan sosial dapat berpengaruh terhadap penurunan pandemi Covid-19 di Provinsi Jawa Barat terjadi pada periode $(t-1),(t-2)$, dan seterusnya. Selanjutnya, regresi data panel telah melalui tingkatan penentuan model estimasi yang tepat, antara lain:

Tabel II. Penentuan Model Estimasi

\begin{tabular}{ccc}
\hline Uji & Prob & Model Estimasi \\
\hline Chow & 0,0456 & Fixed Effect \\
Hausman & 0,7777 & Random Effect \\
Lagrange Multiplier & 0,2546 & Least Square \\
\hline
\end{tabular}

Tabel III. Uji Asumsi Klasik

\begin{tabular}{lccc}
\hline \multicolumn{1}{c}{ Uji } & Nilai Rujukan & Hasil & Kesimpulan \\
\hline Normalitas & $($ p-value $)>0,05$ & 0,0979 & Terdistribusi Normal \\
Hausman & VIF $<10$ & 3,61 & Tidak terdapat multikolinearitas \\
Autokorelasi & $(p$-value $)<0,05$ & 0,0000 & Tidak terdapat autokorelasi \\
\hline
\end{tabular}

Namun, dalam penelitian ini juga membandingkan dengan melakukan regresi sederhana berdasarkan penelitian yang dilakukan Agus (2009) dengan menghilangkan variabel kontrol. Adapun model persamaan regresi sederhana pada penelitian ini, sebagai berikut:

$$
\mathrm{Y}_{i t}=\alpha_{i t}+\beta_{1} \mathrm{D}_{i(t-k)}+\mathrm{e}_{i t}
$$

Tujuan daripada membandingkan hasil regresi FGLS dengan model regresi sederhana yaitu untuk dapat memperkuat analisa pengaruh pembatasan sosial pada rata-rata penambahan kasus Covid-19 di Provinsi Jawa Barat.

Data yang digunakan berbentuk data panel dengan penaksiran koefisien regresi menggunakan pendekatan Feasible Generalized Least Squares (FGLS). Pendekatan tersebut tepat digunakan dalam penelitian ini, sebab apabila data panel terdiri dari data variabel bebas yang berulang, maka dapat menggunakan pendekatan FGLS (Liu dkk, 2020).

Jumlah pengamatan objek $\mathrm{i}=1, \ldots, 27$ dan jumlah waktu yang berbeda pada setiap objek yang diamati $\mathrm{t}=1, \ldots, \tau$. Hal ini disebabkan hanya tersedianya data variabel rata-rata penambahan kasus harian Covid-19 dan pembatasan sosial pada setiap periode waktu selama 17 periode. Model persamaan untuk mengetahui periode waktu terjadinya penurunan kasus harian Covid-19 pada saat penerapan pembatasan sosial seperti deskripsi data pada Tabel I. Adapun referensi model penelitian ini berdasarkan pada penelitian terdahulu yang dilakukan oleh Qin dkk (2020), Liu dkk (2020), Lee dkk (2020), dan Ekananda (2006).

Pada Tabel III menunjukan bahwa data penelitian ini terdistribusi normal, tidak terdapat multikolinearitas, dan tidak terdapat autokorelasi. Sehingga, data ini layak untuk di lakukan pengujian lebih lanjut.

\section{Hasil}

Tabel IV menunjukkan bahwa pembatasan sosial berpengaruh positif signifikan terhadap penurunan pandemi di Provinsi Jawa Barat dengan tingkat signifikansi sebesar 1\%. Rata-rata penambahan kasus harian Covid-19 akan menurun sebesar 2,5 
orang pada periode pembatasan sosial yang sedang berlangsung di Provinsi Jawa Barat. Sehingga, dengan menerapkan pembatasan sosial akan mencegah sebesar rata-rata 2,5 orang untuk tidak terpapar virus Covid-19. Namun, apabila variabel bebas yang lain dihilangkan dan fokus pada pembatasan sosial terhadap rata-rata penambahan kasus harian Covid-19 saja, maka hasil regresi menunjukkan bahwa pembatasan sosial akan menurunkan jumlah kasus harian yang lebih signifikan yaitu sebesar 5,5 orang dapat dicegah tertular Covid-19.

Kepadatan penduduk juga berpengaruh negatif signifikan terhadap penurunan pandemi Covid-19 di Provinsi Jawa Barat dengan tingkat signifikansi sebesar $1 \%$. Apabila kepadatan penduduk meningkat $1 \mathrm{jiwa} / \mathrm{km}$, maka rata-rata penambahan kasus harian Covid-19 akan meningkat sebesar 0,16 orang di Provinsi Jawa Barat. Kemudian, PDRB per kapita berpengaruh positif, namun tidak signifikan terhadap rata-rata penambahan kasus Covid-19 di Provinsi Jawa Barat.

Tabel IV. Hasil Regresi Sederhana Rata-rata Penambahan Kasus Harian Covid-19

\begin{tabular}{|c|c|c|c|}
\hline Variabel & Coef & SE & Prob \\
\hline Pembatasan Sosial & $-5,52 * * *$ & 8,67 & 0,0000 \\
\hline cons & 8,19 & 3,41 & \\
\hline $\mathrm{N}$ & 405 & & \\
\hline$R$-Squared & 0,0804 & & \\
\hline F-Stat & $0,0000 * * *$ & & \\
\hline
\end{tabular}

Tabel V. Hasil Regresi FGLS Rata-rata Penambahan Kasus Harian Covid-19

\begin{tabular}{llrr}
\hline Variabel & Coef & SE & Prob \\
\hline Pembatasan Sosial & $-2,504 * * *$ & 12,39 & 0,0000 \\
Kepadatan Penduduk & $0,159^{* * *}$ & 9,42 & 0,0000 \\
PDRB per kapita & $-2,110$ & 13,97 & 0,4620 \\
Tingkat Pendidikan & $0,067^{* * *}$ & 0,50 & 0,0000 \\
Tingkat Mobilitas & $5,639^{* *}$ & 4,09 & 0,0134 \\
Tingkat Pengangguran & $-5,779^{* * *}$ & 5,42 & 0,0000 \\
Jumlah Tenaga Kesehatan & $-9,590^{* * *}$ & 11,02 & 0,0000 \\
Presentase Penduduk Miskin & $0,105^{* * *}$ & 3,44 & 0,0000 \\
Angka Harapan Hidup & $7,338^{* * *}$ & 6,48 & 0,0000 \\
cons & $-464,798$ & 435,66 & \\
N & 459 & & \\
$R$-Squared & 0,1127 & & \\
F-Stat & $0,0038^{* * *}$ & & \\
\hline & $* \mathrm{p}<0.1, * * \mathrm{p}<0.05, * * * \mathrm{p}<0.01$ &
\end{tabular}


Hasil regresi membuktikan apabila PDRB per kapita berpengaruh potitif, namun tidak signifikan terhadap rata-rata penambahan kasus harian Covid-19 di Provinsi Jawa Barat dengan tingkat signifikansi sebesar 5\%. Jika terjadi peningkatan PDRB perkapita 1 juta rupiah, maka rata-rata penambahan kasus harian Covid-19 akan menurun sebesar 2,11 orang di Provinsi Jawa Barat.

Sedangkan, tingkat pendidikan berpengaruh negatif signifikan terhadap rata-rata penambahan kasus harian Covid-19 di Provinsi Jawa Barat dengan tingkat signifikansi sebesar 1\%. Jika tingkat pendidikan meningkat 1 persen, maka ratarata penambahan kasus harian Covid-19 akan meningkat sebesar 0,07 orang di Provinsi Jawa Barat.

Hasil regresi menunjukkan apabila tingkat mobilitas meningkat 1 persen, maka rata-rata penambahan kasus harian Covid-19 akan meningkat sebesar 5,64 orang di Provinsi Jawa Barat. Sebaliknya, tingkat pengangguran berpengaruh positif signifikan terhadap penurunan pandemi Covid-19 di Provinsi Jawa Barat dengan tingkat signifikansi sebesar $1 \%$.

Jika tingkat pengangguran meningkat 1 persen, maka rata-rata penambahan kasus harian Covid-19 akan menurun sebesar 5,78 orang di Provinsi Jawa Barat. Jika dibandingkan dengan koefisien hasil regresi variabel lain, maka variabel jumlah tenaga kesehatan paling positif signifikan menurunkan pandemi Covid-19 di Provinsi Jawa Barat.

Hasil regresi membuktikan apabila jumlah tenaga kesehatan meningkat 1 orang, maka ratarata penambahan kasus harian Covid-19 akan menurun sebesar 9,6 orang di Provinsi Jawa Barat. Sebaliknya, persentase penduduk miskin berpengaruh negatif signifikan terhadap prevalensi Covid-19 di Provinsi Jawa Barat.

Apabila persentase penduduk miskin meningkat 1 persen, maka rata-rata penambahan kasus harian Covid-19 akan meningkat sebesar 0,1 orang di Provinsi Jawa Barat. Jumlah tenaga kesehatan dan persentase penduduk miskin memiliki tingkat signifikansi sebesar 1\%. Angka harapan hidup berpengaruh negatif signifikan terhadap rata-rata penambahan kasus harian Covid-19 di Provinsi Jawa Barat dengan tingkat signifikansi sebesar 1\%. Jika angka harapan hidup meningkat 1 tahun, maka rata-rata penambahan kasus harian Covid-19 akan meningkat sebesar 7,34 orang di Provinsi Jawa Barat.

\section{Pembahasan}

\section{Pembatasan Sosial}

Hasil regresi penelitian ini sesuai dengan penelitian Cheng dkk (2020) yang menyatakan bahwa gejala awal pada kasus penderita Covid-19 umumnya ditemukan paling cepat 4-5 hari setelah terpapar Covid-19 yang disebut masa inkubasi. Namun, beberapa kasus pasien baru muncul gejala lebih dari 6 hari setelah terpapar Covid-19 dengan gejala yang lebih ringan. Selama masa inkubasi banyak penderita Covid-19 tidak melakukan pemeriksaan tes untuk mendeteksi apakah telah terinfeksi Covid-19 atau tidak.

Hal ini diakibatkan oleh banyak penderita yang belum mengalami gejala pada masa inkubasi, sehingga penderita masih berasumsi sehat dalam masa inkubasi. Sedangkan, periode pengukuran pembatasan sosial sudah sesuai dengan "Peraturan Gubernur Jawa Barat Nomor 48 Tahun 2020 Pasal 5 " yang menyatakan bahwa periode jangka waktu pembatasan sosial selama satu kali masa inkubasi terpanjang atau empat belas hari. Setelah penderita Covid-19 melewati masa inkubasi dan melakukan tes pemeriksaan, maka pasien perlu melewati masa isolasi selama 10 hari. Pasien dengan gejala ringan hingga sedang dinyatakan sembuh apabila 3 hari tanpa gejala setelah masa isolasi. Sedangkan, pasien dengan gejala berat perlu menunjukkan hasil negatif pada tes PCR sebanyak 1 kali hari sebelum dinyatakan sembuh dari Covid-19. Oleh sebab itu, dampak dari penurunan kasus Covid-19 tidak dapat dilihat pada periode pembatasan sosial yang sedang berlangsung, melainkan satu periode 
setelahnya.

Hal ini berkesinambungan dengan hasil pada penelitian ini yang menyatakan bahwa pembatasan sosial tidak langsung berdampak pada penurunan pandemi Covid-19 di Provinsi Jawa Barat pada saat periode pembatasan sosial tersebut berlangsung.

Adapun penurunan angka rata-rata penambahan kasus harian Covid-19 baru dapat menunjukkan penurunan setelah lebih dari empat belas hari atau setara dengan periode (t-1) pembatasan sosial. Hasil penelitian ini diperkuat oleh data BPS (2021) bahwa sebanyak 88\% masyarakat Provinsi Jawa Barat telah menerapkan pembatasan sosial dan sebanyak $95 \%$ masyarakat Provinsi Jawa Barat telah mengetahui adanya kebijakan pembatasan sosial. Penerapan pembatasan sosial di Provinsi Jawa Barat lebih tinggi, jika dibandingkan dengan nasional sebesar $72 \%$.

\section{Faktor Pendukung Keberhasilan Pembatasan Sosial di Provinsi Jawa Barat}

- Perilaku menghindari pertemuan atau antrian Sebesar 78\% masyarakat Provinsi Jawa Barat telah menerapkan perilaku menghindari pertemuan atau antrian.

- Perilaku tidak berjabat tangan

Sebesar 80\% masyarakat Provinsi Jawa Barat telah menerapkan perilaku tidak berjabat tangan

- Menghindari penggunaan transportasi umum Pembatasan sosial menyebabkan banyak transportasi umum ditutup. Hal ini membuat 82\% masyarakat Provinsi Jawa Barat telah mengurangi penggunaan transportasi umum

- Menjaga jarak 1-2 meter dari orang lain ketika diluar rumah

- Pembatasan sosial memberikan perilaku positif pada $65 \%$ masyarakat Provinsi Jawa Barat untuk menjaga jarak 1-2 meter dari orang lain ketika diluar rumah (BPS, 2021).

\section{Dampak Pembatasan Sosial Terhadap Ekonomi di Provinsi Jawa Barat}

Menurut penelitian Feyisa (2020) bahwa ekonomi di Indonesia termasuk di Provinsi Jawa Barat berpotensi mengalami dampak dari pandemi Covid-19 pada sektor ekonomi utama seperti perdagangan, manufaktur, sektor jasa, pariwisata dan penerbangan. Hal ini sejalan dengan kondisi yang terjadi di Provinsi Jawa Barat saat pembatasan sosial berlangsung. Berdasarkan Keputusan dan Peraturan Gubernur Provinsi Jawa Barat nomor 443/Kep.221-Hukham/2020 sampai dengan 443/Kep.33-Hukham/2021, maka banyak sektor jasa, pariwisata dan penerbangan yang dibatasi bahkan ditutup sementara waktu. Selain itu sektor perdagangan dan manufaktur juga mengalami gangguan. Hal ini disebabkan oleh jumlah jam kerja karyawan dan operasional yang dibatasi. Pembatasan sosial juga berdampak pada penutupan beberapa akses jalan, sehingga ini mengurangi kelancaran pada sektor perdagangan dan manufaktur (Feyisa, 2020).

Data BPS (2021) menunjukkan bahwa sebesar 45,44\% masyarakat di Provinsi Jawa Barat mengalami penurunan pendapatan akibat penerapan pembatasan sosial. Sebanyak 31\% masyarakat di Provinsi Jawa Barat mengalami penurunan pendapatan lebih dari $70 \%$ sebelum pembatasan sosial diterapkan, sedangkan sebanyak 7\% masyarakat di Provinsi Jawa Barat mengalami penurunan pendapatan lebih dari $75 \%$ sebelum pembatasan sosial diterapkan.

Lapangan usaha yang mengalami penurunan pendapatan pada masa pembatasan sosial di Provinsi Jawa Barat adalah jasa pendidikan dan jasa pemerintahan. Hal ini sejalan dengan hasil penelitian ini bahwa dalam kebijakan pembatasan sosial, maka pekerja diutamakan untuk bekerja dari rumah dan relokasi anggaran (BPS, 2021).

Dampak pembatasan sosial di Provinsi Jawa Barat menyebabkan 57,51\% masyarakat Provinsi Jawa Barat mengalami peningkatan pengeluaran. Hal ini disebabkan oleh perubahan perilaku 
pengeluaran masyarakat. Lebih dari 34,99\% terjadi peningkatan pengeluaran pada saat pembatasan sosial diterapkan. Peningkatan pengeluaran ini diakibatkan masyarakat membutuhkan lebih banyak pulsa/paket data, stok bahan makanan, keperluan kesehatan, stok makanan/minuman kemasan siap jadi selama masa penerapan pembatasan sosial (BPS, 2021).

Pengeluaran tertinggi pertama pada masa pembatasan sosial menurut data BPS (2021) terjadi pada keperluan kesehatan sebesar 76,19\%. Hal ini disebabkan pada awal pembatasan sosial di Provinsi Jawa Barat terjadi peningkatan harga kebutuhan kesehatan seperti masker dan hand sanitizer yang sangatlah tinggi dari biasanya.

Menurut penelitian Raditya (2020) di Provinsi Jawa Barat terjadi kenaikan harga berlipat-lipat pada masker, hand sanitizer dan alat pelindung diri sebagai alat preventif dari penularan pandemi Covid-19 di awal pandemi Covid-19. Sebanyak tiga kasus perihal penimbunan alat kesehatan tersebut terjadi di Provinsi Jawa Barat.

Keterbatasannya transportasi umum membuat sebesar 9,92\% harga transportasi umum meningkat (BPS, 2021). Hal ini diakibatkan sangat terbatasnya transportasi umum yang diperbolehkan beroperasi selama pembatasan sosial. Adapun transportasi umum yang dapat beroperasi diwajibkan untuk dapat mengurangi kapasitas penumpang.

Pembatasan sosial menyebabkan terbatasnya aktivitas masyarakat untuk berbelanja langsung di pasar, sehingga banyak masyarakat yang beralih pada belanja online guna memenuhi kebutuhan sehari-hari tanpa perlu keluar rumah. Hal ini menyebabkan tingkat aktivitas belanja online masyarakat di Provinsi Jawa Barat menurut BPS (2021) mengalami peningkatan pada masa pembatasan sosial diterapkan.

\section{Kepadatan Penduduk}

Data BPS (2020) menunjukkan Kabupaten/Kota dengan kepadatan penduduk terendah dan tertinggi di Provinsi Jawa Barat, yaitu Kabupaten Pangandaran dan Kota Cimahi.

Tabel VI. Perbandingan Data Kepadatan

Penduduk dengan Rata-Rata Penambahan Kasus Harian

\begin{tabular}{ccc}
\hline & Kab Pangandaran & Kota Cimahi \\
\hline KP & 398 & 15.798 \\
RPKH & 0,44 & 9,06 \\
\hline
\end{tabular}

Sumber: BPS dan Pikobar Jawa Barat (2020)

Pada Tabel VI di atas memperlihatkan semakin tinggi kepadatan penduduk, maka semakin tinggi angka rata-rata penambahan kasus harian Covid19 di daerah tersebut. Hasil penelitian ini berkesinambungan dengan penelitian Taipale dkk (2020). Selain itu, hasil penelitian ini sesuai dengan penelitian yang pernah dilakukan Jawad (2020) bahwa apabila kepadatan penduduk di suatu daerah meningkat, maka kasus Covid-19 di daerah tersebut akan meningkat. Hasil penelitian ini juga berkesinambungan dengan penelitian yang dilakukan oleh Zhong dkk (2020) bahwa kepadatan penduduk adalah salah satu faktor penyebaran pandemi Covid-19, maka data kepadatan penduduk di suatu daerah dapat bermanfaat bagi pembuat kebijakan untuk mengenali target populasi dalam mencegah penularan Covid-19 dan pendidikan kesehatan.

\section{PDRB per Kapita}

Walaupun dapat menurunkan penambahan kasus harian Covid-19, namun hasil penelitian ini tidak signifikan. Hal ini disebabkan oleh moral hazard seseorang, jika pendapatan seseorang semakin meningkat, maka daya beli masyarakat untuk berkumpul bersama semakin meningkat.

Hasil penelitian ini berkesinambungan dengan penelitian Maliszewska \& Mattoo (2020) bahwa kasus Covid-19 berhubungan dengan PDRB per kapita. Maliszewska dan Mattoo (2020) berpendapat bahwa apabila terjadi kenaikan kasus Covid-19, maka PDB akan menurun. Jika 
dibandingkan dengan penelitian ini, maka peningkatan PDRB per Kapita akan menurunkan jumlah kasus Covi-19. Selain itu, hasil penelitian ini sama dengan grafik pada Gambar 1 yang menunjukkan bahwa terdapat hubungan yang selaras antara grafik pertumbuhan kasus Covid-19 dan grafik pertumbuhan ekonomi di Provinsi Jawa Barat.

\section{Tingkat Pendidikan}

Hasil penelitian ini berkesinambungan dengan hasil survei sosial demografi oleh BPS (2021) bahwa tingkat pendidikan yang kurang peduli terhadap Covid-19 di Provinsi Jawa Barat justru berasal dari tingkat pendidikan di atas SMA. Nilai kurang peduli terhadap Covid-19 di Provinsi Jawa Barat tertinggi pada tingkat pendidikan DIV dan S1.

Tingkat pendidikan juga berhubungan dengan sektor pekerjaan seseorang. Apabila semakin tinggi tingkat pendidikan, maka kemungkinan seseorang tersebut untuk bekerja di perkantoran akan semakin besar. Hal ini berhubungan dengan faktor penyumbang terbesar angka positif Covid19 terbesar di Provinsi Jawa Barat yang berasal dari cluster perkantoran.

Menurut Sailer dkk (2020) bahwa dalam krisis pandemi Covid-19 diharapkan pendidikan menjadi dasar individu untuk merespons secara memadai agar dapat mencari informasi terkait Covid-19 yang pada akhirnya berdampak pada perilaku individu tersebut. Jika dilihat pada hasil penelitian ini bahwa dasar pendidikan pada masyarakat di Provinsi Jawa Barat tidak berpengaruh pada hasil yang diharapkan untuk mengurangi kasus Covid-19 di Provinsi Jawa Barat.

Berdasarkan penelitian Solomon (1993) terdapat beberapa faktor yang mempengaruhi tingkat pendidikan tidak berpengaruh terhadap rata-rata penambahan kasus harian Covid-19, antara lain:
- Dasar ilmu pengetahuan pada individu yang tidak digunakan individu tersebut untuk menerapkan perilaku sesuai ilmu pengetahuan yang dimiliki oleh individu tersebut.

- Perbedaan individu dalam pengetahuan ilmiah secara umum membatasi individu tertentu untuk sepenuhnya memahami informasi secara kompleks.

- Penolakan pribadi terhadap ilmu pengetahuan yang dapat mempengaruhi individu tertentu untuk tidak mengikuti anjuran yang berlaku dalam menyikapi permasalahan ilmu pengetahuan.

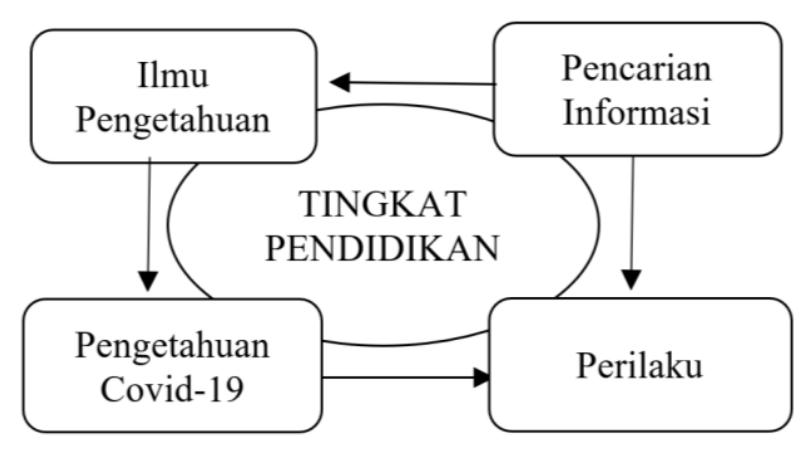

Gambar 3. Hubungan tingkat pendidikanterhadap perilaku kepatuhan pencegahan Covid-19 (Sailer dkk, 2020)

Pada akhirnya masyarakat yang pada dasarnya sudah memiliki pengetahuan Covid-19, tidak dapat mengendalikan krisis pandemi Covid-19 di Provinsi Jawa Barat.

Tingkat pendidikan menurut Sailer dkk (2020) secara psikologis dapat mempengaruhi perilaku seseorang untuk ikut serta membantu mengurangi pandemi Covid-19 melalui tahapan pencarian informasi Covid-19, ilmu pengetahuan yang dimiliki, dan pengetahuan terkait Covid-19.

Jika membandingkan hasil penelitian ini dengan penelitian Sailer dkk (2020) pada Gambar 3, maka terdapat beberapa faktor yang tidak berjalan dengan baik pada masyarakat Provinsi Jawa Barat guna menghasilkan perilaku yang 
diharapkan dapat ikut serta membantu menurunkan pandemi.

\section{Tingkat Mobilitas}

Hasil penelitian ini sejalan dengan penelitian Abedi dkk (2020) yang menyatakan bahwa semakin tinggi tingkat mobilitas di suatu penduduk, maka akan semakin tinggi jumlah kasus infeksi Covid-19 di daerah tersebut. Oleh sebab itu, hasil penelitian ini dapat dijadikan sebagai acuan pemerintah untuk menerapkan pembatasan mobilitas sesuai penelitian yang dilakukan oleh Prawoto dkk (2020) bahwa dengan melakukan pembatasan mobilitas, maka dapat mengurangi penyebaran pandemi Covid-19.

Hasil penelitian ini sesuai dengan data BPS (2021) bahwa sebanyak $80 \%$ masyarakat laki-laki dan $84 \%$ masyarakat perempuan di Provinsi Jawa Barat tidak melakukan mobilitas di saat pandemi berlangsung.

\section{Tingkat Pengangguran}

Jika terjadi penurunan tingkat pengangguran, maka rata-rata penambahan kasus harian Covid-19 akan meningkat. Walaupun tingkat pengangguran dapat menurunkan pandemi Covid-19, namun efek dari pengangguran tidak baik untuk sektor ekonomi. Meningkatnya tingkat pengangguran berarti semakin sedikit masyarakat bekerja di luar rumah dan berinteraksi satu sama lain. Menurut penelitian Feyisa (2020) yang menyatakan bahwa pandemi Covid-19 mempengaruhi dunia kerja di tiga sektor utama yaitu kuantitas pekerjaan, kualitas pekerjaan, dan karyawan yang dirumahkan. Jika dibandingkan dengan data BPS (2020) bahwa penelitian yang dilakukan oleh Feyisa (2020), maka akan menghasilkan keadaan yang berkesinambungan dengan kondisi yang terjadi di Provinsi Jawa Barat.

Pertama, kuantitas pekerjaan, baik pengangguran maupun setengah pengangguran. Banyak karyawan di Provinsi Jawa Barat yang mengalami penurunan jam kerja produktif menjadi
3 hari kerja dalam seminggu, sehingga intensitas kantor menurun. Penurunan intensitas kantor ini sangat berpengaruh pada penurunan kasus positif Covid-19 terbesar di Provinsi Jawa Barat yang berasal dari cluster perkantoran. Hal ini akan berdampak pada sektor yang kedua yaitu kualitas pekerjaan. Kualitas pekerjaan yaitu gaji dan akses perlindungan sosial menjadi berkurang.

Ketiga, efek spesifik kelompok yang lebih rentan terhadap pasar tenaga kerja seperti karyawan kontrak banyak dirumahkan di Provinsi Jawa Barat. Hal ini akan menjadi beban perekonomian di Provinsi Jawa Barat sama halnya dengan penelitian Kharis (2011) yang menyatakan bahwa tenaga kerja yang menjadi pengangguran di suatu daerah akan membebankan perekonomian daerah tersebut, sehingga pertumbuhan ekonomi di daerah tersebut akan menurun.

Sebesar 49,1\% masyarakat di Provinsi Jawa Barat menjadi pengangguran akibat dampak pandemi Covid-19. Hal ini sangat mempengaruhi penurunan kasus Covid-19 di Provinsi Jawa Barat (BPS, 2021). Jika Gambar 1 dibandingkan dengan penelitian yang dilakukan oleh Kharis (2011), maka akan menghasilkan keadaan yang berkesinambungan dengan kondisi yang terjadi di Provinsi Jawa Barat. Pada Gambar 1 terlihat bahwa pertumbuhan ekonomi yang menurun pada Triwulan ke-IV, jika dibandingkan pada TriwulanIII Tahun 2020.

Namun, bukanlah yang diharapkan untuk meningkatkan angka pengangguran, karena secara ekonomi tidak baik, tetapi mencegah terjadinya aktifitas diluar rumah agar interaksi pegawai satu sama lain dipersempit. Jika dibandingkan, terjadinya peningkatan pengangguran dan penurunan jumlah kasus Covid-19, hal ini sesuai dengan terjadinya penurunan pertumbuhan ekonomi pada Triwulan ke-IV q to q di Provinsi Jawa Barat.

\section{Jumlah Tenaga Kesehatan}

Tenaga kesehatan pada penelitian ini antara lain 
dokter, Dokter, Bidan, Perawat, Farmasi, dan Ahli Gizi (BPS, 2020). Pentingnya tenaga kesehatan dalam menurunkan pandemi Covid-19 di Provinsi Jawa Barat terlihat dari angka penurunan sebesar 7,03 orang. Hal ini sejalan dengan penelitian McDougall dkk (2020) bahwa tenaga kesehatan adalah sumber daya perawatan kesehatan yang vital.

Tenaga kesehatan di Provinsi Jawa Barat telah berhasil melakukan gerakan pencegahan atau preventif melalui distribusi flyer dan kampanye 5M dan 3T agar dapat menurunkan rata-rata peningkatan Covid-19 di Provinsi Jawa Barat. 5M dan 3T yang dapat dipahami, diterima, dan dilaksanakan oleh masyarakat Provinsi Jawa Barat, antara lain: Menggunakan masker; Mencuci tangan memakai sabun dengan air yang mengalir; Menjaga jarak; Menjauhi kerumunan; Membatasi mobilitas dan interaksi; Testing; Tracing; dan Treatment.

\section{Persentase Penduduk Miskin}

Pentingnya peran pemerintah untuk tetap menekan angka persentase penduduk miskin di Provinsi Jawa Barat. Apabila pemerintah menekan angka persentase penduduk miskin, maka akan menekan pula rata-rata penambahan kasus harian Covid-19 di Provinsi Jawa Barat.

Penelitian ini sesuai dengan penelitian Fauzan dkk (2020) yang menyatakan bahwa pandemi Covid-19 telah menghilangkan sumber penghasilan penduduk miskin di desa di Provinsi Jawa Barat. Mereka tidak dapat bekerja, bahkan kehilangan pekerjaan, serta harus menetap di rumah untuk mencegah penularan Covid-19. Hal ini membuat penduduk miskin di daerah tersebut terpaksa tetap bekerja di luar rumah setelah kebijakan pembatasan sosial diterapkan guna tetap mendapatkan sumber penghasilan untuk bertahan hidup.

Kekurangan ekonomi ini membuat penduduk miskin, rentan terhadap penularan Covid-19. Selain terpaksa untuk tetap bekerja diluar rumah, sebagian besar dari mereka tidak mempunyai asuransi kesehatan untuk perlindungan di masa pandemi Covid-19. Maka tidak heran bahwa menurut penelitian yang dilakukan oleh Abedi dkk (2020) bahwa semakin tinggi tingkat persentase penduduk miskin di suatu daerah, maka tingkat kematian pada penderita Covid-19 akan semakin tinggi di daerah tersebut.

Dampak pembatasan sosial juga sangat membuat penduduk miskin semakin sulit. Hal ini disebabkan meningkatnya harga kebutuhan alat kesehatan di masa pandemi. Daya beli terhadap alat kesehatan semakin menurun pada sebagian besar penduduk miskin di Provinsi Jawa Barat.

\section{Angka Harapan Hidup}

Hasil penelitian ini menunjukkan bahwa masyarakat dengan angka harapan hidup yang tinggi justru merasa lebih kuat dalam masa pandemi Covid-19 di Provinsi Jawa Barat. Padahal angka harapan hidup yang tinggi tidak berpengaruh pada seberapa kuat seseorang bertahan jika terserang Covid-19. Hal ini disebabkan oleh bukan tingginya angka harapan hidup seseorang, namun seberapa tinggi antibodi di dalam tubuh untuk membantu daya tahan tubuh seseorang dalam melawan virus Covid-19 yang akan masuk di dalam tubuh seseorang tersebut.

Kekeliruan ini membuat pandangan yang salah pada seseorang yang merasa memiliki angka harapan hidup yang tinggi daripada yang lain (Hall, 2020). Sehingga, angka harapan hidup yang tinggi justru meningkatkan rata-rata penambahan kasus harian Covid-19 di Provinsi Jawa Barat.

Jika dibandingkan dengan variabel tingkat pendidikan, maka variabel angka harapan hidup memiliki hasil yang sama pada penelitian ini yaitu sama-sama berpengaruh negatif signifikan terhadap rata-rata penambahan kasus harian Covid-19 di Provinsi Jawa Barat.

Kurang pedulinya pada permasalahan pandemi Covid-19 menurut data BPS (2021) berasal dari masyarakat berpendidikan tinggi. 
Sebagian besar orang yang berpendidikan tinggi akan berpendapat bahwa orang yang berpendidikan lebih rendah akan memiliki angka harapan hidup yang lebih rendah daripada mereka. Selanjutnya, orang yang berpendidikan tinggi pada umumnya bekerja di perkantoran.

Oleh karena itu, salah satu penyumbang angka positif Covid-19 terbesar di Provinsi Jawa Barat berasal dari cluster perkantoran. Hal ini sesuai dengan data BPS (2021) bahwa sebanyak 57,18\% pekerja laki-laki dan $46,55 \%$ pekerja perempuan tidak dapat melakukan work from home (WFH), serta sebanyak 50,9\% pekerja di Provinsi Jawa Barat masih bekerja pada saat pandemi berlangsung. Perkantoran didominasi oleh generasi Z dan Milenial yang umumnya lahir pada rentang tahun 1981-2012. Kedua generasi ini menurut BPS (2021) merupakan generasi yang paling rendah indeks perilaku ketaatan dibandingkan generasi sebelumnya pada masa pembatasan sosial diterapkan. Pada pekerja yang masih bekerja selama masa pandemi di Provinsi Jawa Barat, sebanyak 38,33\% kurang peduli terhadap situasi pandemi yang terjadi. Semua ini dapat menyumbang faktor terjadi cluster perkantoran di Provinsi Jawa Barat.

\section{Limitasi Penelitian}

Pada penelitian ini terdapat kekurangan yaitu keterbatasan data yang tidak lengkap di setiap periode waktu. Sehingga, terdapat pengulangan data entry khusus pada variabel bebas di setiap periode waktu, oleh karena itu menggunakan pendekatan FGLS. Hal ini disebabkan rentang waktu yang dipakai berdasarkan Keputusan Gubernur Jawa Barat.

\section{Kesimpulan dan Saran}

Berdasarkan hasil penelitian, pembatasan sosial mempengaruhi penurunan pandemi Covid-19 secara signifikan di Provinsi Jawa Barat, sehingga penelitian ini dapat dijadikan salah satu acuan untuk mengambil kebijakan yang tepat dalam memerangi pandemi Covid-19.

Selain itu, tidak hanya pembatasan sosial yang mempengaruhi penurunan pandemi Covid-19 secara signifikan di Provinsi Jawa Barat, melainkan kepadatan penduduk, tingkat pengangguran dan jumlah tenaga kesehatan membantu menurunkan pandemi Covid-19 secara signifikan di Provinsi Jawa Barat. Walaupun PDRB per kapita membantu menurunkan pandemi Covid-19 di Provinsi Jawa Barat, namun tidak signifikan. Sementara itu, tingkat pendidikan, tingkat mobilitas, persentase penduduk miskin dan angka harapan hidup tidak membantu menurunkan rata-rata penambahan kasus harian Covid-19 di Provinsi Jawa Barat.

Dari hasil penelitian ini, penulis menyarankan bagi peneliti selanjutnya dapat menganalisa tahapan yang belum tercapai pada masyarakat Provinsi Jawa Barat untuk menghasilkan perilaku yang diharapkan mengurangi pandemi Covid-19 di Provinsi Jawa Barat.

\section{Daftar Pustaka}

Abedi, V., Olulana, O., Avula, V., Chaudhary, D., Khan, A., Shahjouei, S., Li, J., \& Zand, R. (2020). Racial, Economic, and Health Inequality and COVID-19 Infection in the United States. Journal of Racial and Ethnic Health Disparities.

https://doi.org/10.1007/s40615-020-00833-4 BPS. (2019). Statistik Mobilitas Penduduk dan Tenaga Kerja. Badan Pusat Statistik Jakarta. BPS. (2020). Badan Pusat Statistik Provinsi Jawa Barat. https://jabar.bps.go.id/

BPS. (2021). Hasil Survei Sosial Demografi Dampak Covid-19 Provinsi Jawa Barat. Badan Pusat Statistik Provinsi Jawa Barat. Badan Pusat Statistik Provinsi Jawa Barat.

BPS Jawa Barat. (2020). Badan Pusat Statistik Provinsi Jawa Barat. https://jabar.bps.go.id/ Brundtland, G.H., \& Sy, E.A. (2019). A World at Risk: Annual Report on Global Preparedness for Health Emergencies. Global Preparedness Monitoring Board. GPMB: 1-48. 
Cheng, H. Y., Jian, S. W., Liu, D. P., Ng, T. C., Huang, W. T., \& Lin, H. H. (2020). Contact Tracing Assessment of COVID-19 Transmission Dynamics in Taiwan and Risk at Different Exposure Periods before and after Symptom Onset. JAMA Internal Medicine, 180(9), 1156-1163.

https://doi.org/10.1001/jamainternmed.2020.202 $\underline{0}$

Fauzan, E., Harimurti, Y., Purbasari, I., \& Yulianingsih, I. (2020). Regulation Village Funds as Cash Direct Aid for Poor People in Rural Area due to Covid-19 Pandemic in Indonesia. September.

https://doi.org/10.4108/eai.26-9-2020.2302556

Fang, H., Wang, L., \& Yang, Y. (2020). Human Mobility Restrictions and The Spread of The Novel Coronavirus (2019-nCoV) in China. Journal of Public Economics, 191, 104272. https://doi.org/10.1016/j.jpubeco.2020.1042 $\underline{72}$

Feyisa, H.L (2020). The World Economy at COVID-19 Quarantine: Contemporary Review. International Journal of Economics, Finance and Management Sciences, 8(2), 63.

https://doi.org/10.11648/j.ijefm.20200802.11

Goolsbee, A., \& Syverson, C. (2021). Fear, Lockdown, and Diversion: Comparing Drivers of Pandemic Economic Decline 2020. Journal of Public Economics, 193, 104311.

https://doi.org/10.1016/j.jpubeco.2020.104311

Gujarati, D.N. (1988). Basic Econometrics, Third Edition. McGraw-Hill International Book Company, West Point.

Hall, A.J., Clement, N.D., Farrow, L., MAcLullich, A.M.J., Dall, G.F., Scoot, C.E.H., Jenkins, P.J., White, T.O., \& Duckwprth, A.D. (2020). Impact-Scot Report on Covid-19 and Hip Fractures A Multicentre Study Assessing Mortality, Predictors, of Early SARS-CoV-2 Infection, and The Effects of Social Lockdown on Epidemiology. The Bone \& Joint Journal, 102(9),1219-28,

https://doi.org/10.1302/0301620X.102B9.BJJ-2020-1100.R1
Jawad, A. J. (2020). Effectiveness of population density as natural social distancing in COVID19 spreading. Ethics, Medicine and Public Health, 15, 100556.

https://doi.org/10.1016/j.jemep.2020.100556

Jdih.bandung.go.id. (2021). Jaringan Dokumentasi dan Informasi Hukum. https://jdih.bandung.go.id/home/produkhukum/daerah

Kharis, M. (2011). Pengaruh Faktor-Faktor Kependudukan Terhadap Pertumbuhan Ekonomi Di Kabupaten Pemalang. 47.

Liu, H., Manzoor, A., Wang, C., Zhang, L., \& Manzoor, Z. (2020). The COVID-19 outbreak and affected countries stock markets response. International Journal of Environmental Research and Public Health, $17(8), 1-19$.

https://doi.org/10.3390/ijerph17082800

Maliszewska, M., \& Mattoo, A. (2020). The Potential Impact of COVID-19 on GDP and Trade. Policy Research Working Paper, 9211, 2. http://documents1.worldbank.org/curated/e $\mathrm{n} / 295991586526445673 / \mathrm{pdf} /$ The-PotentialImpact-of-COVID-19-on-GDP-and-TradeA-Preliminary-Assessment.pdf

Raditya, R. (2021). Urgensi Penemuan Hukum Oleh Hakim Sebagai Upaya Untuk Mewujudkan Keadilan dan Kepastian Hukum Dalam Penanganan Kasus Penimbunan Masker dan Hand Sanitizer di Masa Wabah Covid-19. Universitas Tarumanegara. http://repository.untar.ac.id/id/eprint/31606

McDougall, R. J., Gillam, L., Ko, D., Holmes, I., \& Delany, C. (2021). Balancing health worker well-being and duty to care: An ethical approach to staff safety in COVID19 and beyond. Journal of Medical Ethics, 47(5), 318-323. https://doi.org/10.1136/medethics-2020106557

Pikobar.jabarprov.go.id. (2021). Pusat Informasi dan Koordinasi Covid-19. https://pikobar.jabarprov.go.id/data

Prawoto, N., Purnomo, E. P., \& Zahra, A. A. (2020). The impacts of Covid-19 pandemic on socio-economic mobility in Indonesia. 
International Journal of Economics and Business Administration, 8(3), 57-71. https://doi.org/10.35808/ijeba/486

Sailer, M., Stadler, M., Botes, E., Fischer, F., \& Greiff, S. (2021). Science knowledge and trust in medicine affect individuals' behavior in pandemic crises. European Journal of Psychology of Education. https://doi.org/10.1007/s10212-021-005291

Solomon, J. (1993). Reception and rejection of science knowledge: Choice, style and home culture. Public Understanding of Science, 2(2),

$111-121$. https://doi.org/10.1088/0963-6625/2/2/002

Taipale, J., Romer, P., \& Linnarsson, S. (2020). Population-scale testing can suppress the spread of COVID-19. 1-20. https://doi.org/10.1101/2020.04.27.2007832 $\underline{9}$

WHO. (2020). Coronavirus disease 2019 (COVID-19) Situation Report-80. https://www.who.int/emergencies/diseases/ novel-coronavirus-2019/situation-reports

Zhong, B. L., Luo, W., Li, H. M., Zhang, Q. Q., Liu, X. G., Li, W. T., \& Li, Y. (2020). Knowledge, attitudes, and practices towards COVID-19 among chinese residents during the rapid rise period of the COVID-19 outbreak: A quick online cross-sectional survey. International Journal of Biological Sciences, 16(10), 1745-1752. https://doi.org/10s.7150/ijbs.45221 